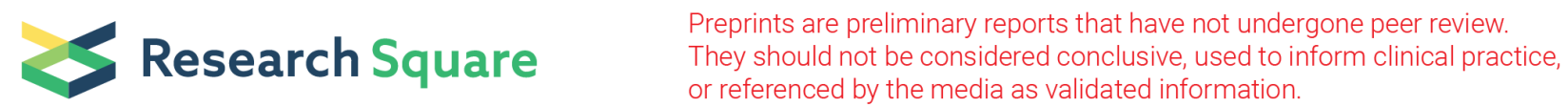

\section{Seed proteins mining for development, nutrition and germination using comparative proteomics analysis in quinoaखChenopodium quinoa willd.)}

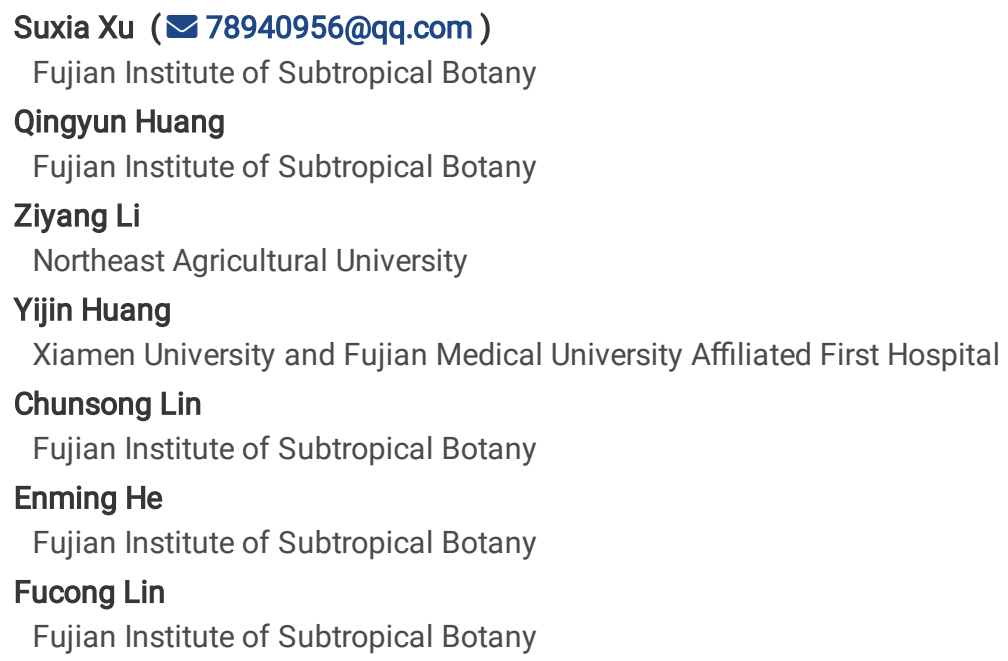

Research article

Keywords: DEP, maturation, Proteomes, Quinoa

Posted Date: March 27th, 2020

DOI: https://doi.org/10.21203/rs.3.rs-19485/v1

License: (c) (i) This work is licensed under a Creative Commons Attribution 4.0 International License. Read Full License 


\section{Abstract}

Background Recently quinoa( Chenopodium quinoa willd., $2 n=4 x=36$ )raises worldwide popularity with its totally nutrition, stress-tolerance, which leads quinoa to a strategic global food from an Andean native crop. However, seed pre-harvest sprouting, saponin contents e.c., restrict greatly quinoa production and popularity. In the study, we successfully used a combinational proteomics of TMT labeling and parallel reaction monitoring (PRM) to assess proteome changes relating to seed maturation conversion in quinoa to help accelerate genetic improvement for quinoa.

Results In total, 6,097 proteins were identified and 4,770 proteins were quantified. Of them, 581 were differential expressed proteins (DEPs). Based on PRM data, seventeen DEPs were identified and quantified, including thirteen down-regulated proteins and four up-regulated proteins. Seventeen DEPs involved in oleanane-type saponins bio-synthesis ( $\beta$-amyrin 28-oxidase), seed generation ( $\beta$-Amylase), seed dormancy (late embryogenesis abundant proteins, Cyprosin), seed nutrition (globulin seed storage proteins), accumulation of sugars under seed desiccation (EARLY-RESPONSIVE TO DEHYDRATION 7 protein), pre-harvest sprouting (seed biotin-containing protein SBP65, ABA-inducible protein PHV A1), and enzymes related promoting seed maturation (bifunctional purple acid phosphatase 26), and pigment biosynthesis (3-Oglucosyltransferase).

Conclusions We present the high-quality proteomics analysis of quinoa assessing proteome changes during seed maturation conversion. Our results summarize a valuable proteome profiles characterizing quinoa seed maturation. The DEPs are candidate for the functional analyses of proteins regulating seed maturation conversion in quinoa, which provide an important first step towards the genetic improvement of quinoa.

\section{Background}

Quinoa, (Chenopodium quinoa Willd., $2 n=4 x=36$ ) a tetraploid native crop that has offered strong subsistence, nutrition, and medicine for Andean indigenous cultures for 8,000 years ( Schlick and Bubenheim, 1996; Bhargava et al., 2006). Quinoa contains outstanding protein content, possesses a balanced amino acid profile compared to common cereal grains, similar to the biological value of protein in milk (Oelke et al., 1992; Wu et al., 2014). It overcomes cereals in the level of lipids, proteins, dietary fibers, vitamins B1, B2, B6, C, E and minerals (Wu et al., 2014). In addition to presenting high nutritional quality, it is also noteworthy that quinoa is gluten-free, suitable food products for people with celiac disease (Zevallos et al., 2014; Wu, 2016). Also, quinoa have high salt tolerance and can grow under extremely dry conditions (Ruiz et al., 2016; Walters et al., 2016). Particular adaptations of this species to certain geographical areas gave rise to different ecotype in adaptations to rainfall areas with precipitation of $2000 \mathrm{~mm}$ per year to extremely drought stress of $150 \mathrm{~mm}$ per year (Fuentes et al., 2012). Quinoa has the potential to provide a drought/salt tolerant, nutritious alternative staple food. However, so far, quinoa supply is much insufficient, especially many people are suffering starvation or malnutrition in the world (FAO, 2014). Despite its agronomic potential, quinoa is still an underutilized crop with the objective of enhancing global food security for a growing world population (Massawe et al. 2016). Probably all theses aspects were taken into account by the FAO when it included quinoa in the list of most promising crops for world food security and human nutrition in future (FAO, 2006).

Nutrition accumulation is common concern in quinoa production. Quinoa nutrition is characterized with seed storage proteins, carbohydrate, starch, saponins, vitamins, minerals, i.e (Wu et al., 2014). Of them, seed storage proteins are mainly responsible for seed germination (Aloisi et al., 2016), also make quinoa nutritious. Additionally, quinoa has some unpleasant traits, such as pre-harvest sprouting, unpalatable bitterness of seed coat (Lopes et al., 2019). Pre-harvest sprouting is one big problem in quinoa production, which bugs farmers a lot (Lintschinger et al., 1997; Lopes et al., 2019). It would facilitate genetic improvement to pre-harvest sprouting during seed maturation, if pre-harvest sprouting related proteins could be identified (Burrieza et al., 2019). Quinoa seeds contain a mixture of triterpene glycosides called saponins (David et al., 2017). Saponins are another problem in quinoa production. Although saponins may be beneficial for plant growth (Kuljanabhagavad, et al., 2009), they impart bitterness to the grain (Fiallos-Jurado et al., 2016), and they must be removed before human consumption. To explore saponins biosynthesis proteins during seed maturation can help modify grain flavor in future quinoa production.

Thus, it is much helpful to explore these typical proteins above during seed maturation to accelerate the genetic improvement of quinoa. Proteomics is an efficient tool to help find reliable proteins markers. (David et al., 2017). Fortunately, a high quality genome sequence for quinoa was published. Building on this, here we successfully used a combinational proteomics of TMT and parallel reaction monitoring (PRM) (Peterson et al., 2012) to assess proteome changes relating to seed maturation conversion in Chenopodium quinoa Willd. to help accelerate genetic improvement for quinoa.

\section{Results}

\section{Morphological comparison between two developing stages}


Morphological indexes were measured such as plant height, inflorescence diameter, hundred-grain weight, grain diameter, grain thickness and colors (leaves color, leaf axil color, stem streaks color, inflorescence color, palea color and episperm color) (see Table 1). At morphological level, palea/episperm color and hundred-grain weight showed sharp difference between two developing stages. Grains of 72 days after sewing is in the eve of seed maturation conversion, and grains 84 days after sewing were mature seeds, edible and dry.

\section{Profile of proteome in quinoa}

We performed a comparative proteomics analysis for seed development, nutrition and germination in two developing stages of maturity conversion by using TMT labeling, HPLC fractionation and LC-MS/MS analysis. Totally 6097 proteins were identified and 4770 were quantifiable, based on 17,362 unique peptides. A quantitative Yellow_1 vs Yellow_2 ratio higher than 1.5 was considered to indicate upregulation and a quantitative ratio of less than 0.5 was regarded as down-regulation indication. 1,226 proteins were identified as differentialexpressed proteins (DEPs) between the two stages. Of them, 675 proteins were up-regulated and 551 were down-regulated (Table 2) (Supplementary Table S1). Supplementary Table S1 showed the MS basic information of DEPs identified. Pearson's Correlation Coefficient was calculated to test the repeatability. The result showed good repeatability was obtained (Table 3 \& Figure 2A). Based on the Fisher's exact test,

hierarchical clustering heat maps were made to illustrate the changing amounts of DEPs from each of the pooled samples (Figure $2 \mathrm{~B} \&$ Supplementary Tables S2, 3, 4, 5).

Based on different protein functional classification (such as: GO, Domain, Pathway, Complex), all the categories were collated and filtered with a corrected p-value $<0.05$. For each category, a two-tailed Fisher's exact test was employed to test the enrichment of the DEPs against all identified proteins. The GO enrichment analysis indicated that the enrichment levels of the up-regulated proteins were high while the enrichment levels of the down-regulated proteins were relatively low as shown in Table 5. Most of the identified DEPs appeared to be involved in the molecular function (43.7\%), biological process (39.2\%) and cellular component (17.1\%) ((see Figure 2C\&D, Table 4, 5, \& Supplementary Table S6). The up-regulated proteins mainly grouped in the cell component, molecular function and biological process categories, involving in organelle membrane and membrane-enclosed lumen, mitochondrial/membrane binding, adenyl ribonucleotide/adenyl nucleotide binding, ATPor NTP-dependent helicase activity, and nucleobase-containing compound metabolic process. Supplementary Tables S8 presented the number of DEPs associated with each level GO term according to the GO annotation information of the identified proteins.

The KEGG pathway enrichment analysis showed that the up-regulated proteins were mainly enriched in pathway entries related to phenylpanoid biosynthesis including ubiquonone biosynthesis, flavonoid biosynthesis, and/or stilbenoid, diarylheptanoid, gingerol biosynthesis, ribosome, cutin, suberine and wax biosynthesis. Besides, upregulated proteins were mainly enriched in pathway related to photosynthesis proteins. Down-regulated proteins were mainly enriched in glycolysis/ gluconeogenesis, ribosomal proteins, plant hormone signal transduction, proteins processing in endoplasmic reticulum and plant pathogen interaction (Figure 3).

Subcellular prediction was performed to illustrate the subcellular localization of these DEPs, as shown in Table 6. Most of the up-regulated proteins were localized in the chloroplast (39.0\%), cytoplasm $(29.0 \%)$ and nucleus $(12.0 \%)$, while the most of the down-regulated proteins were distributed in the cytoplasm (33.0\%), chloroplast (29.0\%), and nucleus (19.0\%). The percentage of proteins located in extracellular, vacuolar membrane, and cytoskeleton was similar between down- and up-regulated proteins. The percentage of up-regulated proteins localized in the

chloroplast and plasma membrane was higher than that of down-regulated proteins, while a higher percentage of down-regulated proteins were in cytoplasm and nucleus. In addition, one down-regulated protein localized to the peroxisome, and one localized to the golgi apparatus.

\section{PRM assay results}

TMT assays identified 4770 peptides, and 581 were identified as DEPs between the two seed developing stages. Those DEPs had predicted annotations related to saponins metabolism, pre-harvest sprouting, ubiquitous proteins accumulation, and ABA signaling pathways, likely involving in conferring stage $\$ to stage $\Downarrow$. To confirm the TMT results, a total of 19 peptides were selected for validation using PRM, based on their functional significance, and finally 17 peptides were validated (see Table 7). The high consistency between PRM and TMT quantification results lends confidence to the TMT data. By combining DEPs with their enriched KEGG pathways, we outlined the metabolism characteristic in the maturity development in quinoa.

The DEP, AUR62017037-RA, annotated as ABA-inducible protein PHV A1, was identified as down-regulated proteins in Yellow_1/Yellow_2 (see Table 7). Similarly, the DEP, AUR62014945-RA, annotated as $\beta$-amylase, showed down-regulation trend during seed maturity in Yellow_1/Yellow_2 (see Table 7). The six DEPs, AUR62002139-RA, AUR62015569-RA and AUR62024716-RA, AUR62003182-RA, AUR62006523RA, AUR62025011-RA, were annotated as globulin seed storage protein (see Table 7). They were identified as down-regulated proteins. With 
seeds maturity approaching, these proteins were increasingly expressed. The main component of seed storage proteins is $11 \mathrm{~S}$ or $13 \mathrm{~S}$ globulin in quinoa.

The DEP, AUR62025699-RA, annotated as $\beta$-amyrin 28-oxidase, descended gradually with seeds maturity (see Table 7). The enzyme was essential for oleanane-type saponin biosynthesis. It indicated that saponins biosynthesis decreased with seeds maturity.

Two DEPs, AUR62004613-RA and AUR62022650-RA, belonged to that family of late embryogenesis abundant protein (LEA). Two proteins, AUR62037387-RA and AUR62042308-RA, were identified as seed biotin-containing protein SBP65. A DEP, AUR62013047-RA, was a protein EARLY-RESPONSIVE TO DEHYDRATION 7 located in chloroplastic membrane. Four up-regulation DEPs, a $\beta$-amyrin 28-oxidase, a 3-0glucosyltransferase, a bifunctional purple acid phosphatase 26 and a cyprosin were identified.

\section{Disccussion}

Quinoa is an excellent crop with balanced nutrition and wide adaptations. However, despite its agronomic potential, quinoa is still an underutilized crop with the objective of enhancing global food security for a growing world population. So far quinoa production suffers a lot of problems such as bitterness of saponins, seed maturity consistency, pre-harvest sprouting, nutrition accumulation, and so on, that provide genetic improvement aims. Seed development experienced nutrition accumulation, seed desiccation, pigment biosynthesis, seed dormancy preparation, saponins biosynthesis, and so on. We chose the stages from 72 days to 84 days after sewing for investigation of typical proteins involving in these biology progress using proteomics and PRM. Seventeen typical DEPs during seed maturity conversion were validated and showed obvious dynamic.

The DEP, AUR62025699-RA, was annotated as $\beta$-amyrin 28-oxidase, a saponin bio-synthesis enzyme. Quinoa contains 2 to $5 \%$ saponins, producing an undesirable bitter flavor, found in the external layers of the seeds or leaves (Medina-Meza et al., 2016). According to their saponin content, quinoa varieties have been classified as "sweet" (free or less than $0.11 \mathrm{~g} / 100 \mathrm{~g} \mathrm{DW}$ ) and "bitter" varieties (more than $0.11 \mathrm{~g} / 100 \mathrm{~g}$ DW) (Vega-Galvez et al., 2010). Given the associated bitterness and toxicity of saponins, quinoa is treated to reduce saponin levels by washing, dehulling, or thermal processing(Gomez-Caravaca et al., 2014; Medina-Meza et al., 2016). The process is costly and water-intensive, also can reduce the nutritional value of the seeds (Zurita-Silva et al., 2004). Thus, the development of saponin-free lines is a major breeding objective in quinoa (Zurita-Silva et al., 2014). Oleanane-type triterpenes are the major saponin components in quinoa (Medina-Meza et al., 2016). The enzyme, $\beta$-amyrin 28-oxidase, is essential for oleanane-type saponin biosynthesis (Han et al., 2013, Jo et al., 2017). In the study, expression of the enzyme, $\beta$-amyrin 28-oxidase, indicated increasing trend with seed maturity.

$\beta$-amylases (BAM) are key enzymes of plastidial starch degradation. In the study, the enzyme AUR62014945-RA down-regulated with the maturity in Yellow_1/Yellow_2. It indicated that an amylase inhibitor prevents the function of $\beta$-amylases,

AUR62014945-RA, i.e. the premature hydrolysis of stored starch during seed development (Mundy et al., 1985). The protein AUR62017037-RA, ABA-inducible protein PHV A1, maybe exert a role of an amylase inhibitor in quinoa. ABA-inducible protein PHV A1 inhibited seed germination in aleurone layers during barley maturity (Hong et al., 1988). Pre-harvest sprouting occurred frequently in quinoa production (Fig. 4), and made farmers suffered a lot. The function of ABA-inducible protein PHV A1 is under investigation.

The six DEPs, AUR62002139-RA, AUR62015569-RA, AUR62024716-RA, AUR62003182-RA, AUR62006523-RA, AUR62025011-RA, were annotated as $13 \mathrm{~S}$ globulin seed storage protein 1 and 11 globulin seed storage protein 2. Of them, three DEPs (AUR62003182-RA, AUR62006523-RA, AUR62025011-RA) were vicilin-like seed storage protein, and three DEPs (AUR62002139-RA, AUR62015569-RA, AUR62024716-RA) were legumin-like seed storage protein. The legumin-like proteins (both 11S and/or 13S) were generally much more abundant in quinoa seeds than the vicilin-like proteins (Burrieza et al., 2019). Proteins in quinoa seeds are mainly stored in the embryonic tissue also containing lipid, ash, fiber and saponin while the perisperm is rich in starch (Maldonado and Otegui, 1998; Ando et al., 2002). Of the total protein in mature seeds of quinoa, 37\% proteins are 11S-type globulin called chenopodin, and 35\% of the seed protein are 2S albumin (Dakhili et al., 2019). 11S globulin was the predominant component of quinoa seed storage proteins (Stevens et al., 2006, Dakhili et al., 2019). Accumulation of these proteins indicated approaching maturation. The main component of duckwheat and sweet beet were seed storage proteins, 13S globulin (Aloisi, et al., 2016, Burrieza et al., 2019, Zhou et al., 2019). Quinoa seeds have main storage proteins including globulins, (legumins and vicilins), with rich lysine, methionine and cysteine than common cereals and legumes (Ruales \& Nair, 1992, Burrieza et al. 2019). These globulins were active peptides, reported as the antibacterial, antidiabetic, antihypertensive, chemo-preventive, anti-tumoral and antioxidant activities (Hu et al. 2017, Vilcacundo et al. 2017, 2018). These can be used as a functional ingredient in the food industry (Bendevis \& Jacobsen, 2015, Zhou et al. 2019).

The DEPs, AUR62037387-RA, AUR62042308-RA, were annotated as seed biotin-containing protein SBP65 (seed biotinylated protein of 65 kDa of apparent molecular mass). The proteins are biotin-dependent carboxylases, exerting key roles in basic metabolism in most plants (Dehaye et 
al., 1997). The biotinylated proteins, devoid of any carboxylase activity, were characterized with many physiological and molecular features with late embryo genesis-abundant (LEA) proteins in pea (Dehaye et al., 1997). These peculiar proteins, localized to the cytosol of embryonic cells, perhaps behave as a scavenger or a sink, of free biotin, during late stages of embryo development and is rapidly degraded during germination (Duval et al., 1994, Dehaye et al., 1997,Wang et al., 2012), while the essential role for biotin maybe exerts in seedling establishment from immature embryos. In fact, ABA can induce the expression of the proteins (Dehaye et al., 1997). The report indicated that the expression of the proteins increased with the seed maturity. Quinoa potentially evolved a nice mechanism to prevent from pre-harvest sprouting. Further investigation would help prevent from pre-harvest sprouting in quinoa. The report helps understand the function of these proteins in the embryo development of higher plants.

The proteins, AUR62022650-RA and AUR62004613-RA, annotated as late embryogenesis abundant (LEA) proteins. LEA proteins were involved in ABA-mediated stress responses (Galau et al., 1986). Seeds can suffered desiccation during the maturation phase by the accumulation of high levels of LEA proteins (Avelange-Macherel et al., 2015, Saucedo et al., 2017). It was thought that LEAs have been evolutionarily selection to adopt diversified conditions driven by variations in their cellular environment (Mariana et al., 2019). Two LEAs, AUR62022650-RA and AUR62004613-RA, were accumulated highly, as well as increasing accumulation of 11S globulins and 2S albumin, consistent with increasingly seed desiccation during the maturation phase of quinoa.

The DEP,AUR62028163-RAIwas annotated as protein EARLY-RESPONSIVE TO DEHYDRATION 7. The organelle localization of the DEP has been identified in chloroplast. Early responsive to dehydration (ERD) genes are rapidly induced to respond to dehydration and various other abiotic stresses in plasma, mitochondria and chloroplast membranes (Archana et al., 2012). The ERD protein maybe play a role as a putative sugar transporter as accumulation of sugars increased upon drought (Rizhsky et al., 2004, Pertl-Obermeyer et al., 2016). ABA maybe involved in induction of the protein ((Yamada et al., 2010). Similarly, the protein was induced by seeds suffering the loss of cellular water during the maturation phase. It was not well known that ERDs were expressed earlier than LEAs or not. Its detailed function is under investigation.

The DEP, AUR62028163-RA, was annotated as an anthocyanidin 3-0-glucosyltransferase 7. So far, anthocyanins and betalains never coexist in the same plant species. Interestingly lots of research indicated that genes responsible for anthocyanins biosynthesis were identified in betalainaccumulation plants (Xu et al. 2015, 2016). It is supposed that both betacyanin and anthocyanin metabolisms coexisted in earlier plants and maybe get separated with evolution (Shibendu et al., 2013). Betacyanins are the major pigments present in quinoa. The terminal glycosylation of the aglycone betanidin transfers betanidin to batanins in the biosynthesis pathway of betacyanins (Isayenkova et al., 2006, Das et al., 2013). The similarity of the 3-0-glucosyltransferase, the DEP, AUR62028163-RA, in quinoa to that of anthocyanin 3-0-glucosyltransferase indicates the coexistence of both the pathways of pigment biosynthesis. The protein, AUR62028163-RA, up-regulated the transfer of glucose from UDPglucose to betalains. It indicated that betalains accumulation in seeds decreased as quinoa seeds approached maturation. Color changes are also regarded as the typical sighs of maturity.

The DEP, AUR62013288-RA, was annotated as a bifunctional purple acid phosphatase 26 (PAP). PAPs are key phosphate (Pi)-metabolizing enzymes, help plants with Pi availability and absorption as they are mostly exposed to suboptimal environmental conditions for this vital element (Mohammad et al., 2018). Seeds development is a Pi-consuming phase, and then Pi starvation often occurs. The DEP, AUR62013288RA, decreased as seeds maturation ends. The enzymes can also be regarded as typical proteins during maturation phase of seeds.

The last DEP, AUR62023656-RA, was identified as an up-regulated cyprosin. It indicated that the DEP encoded decreased with seed maturation. Cyprosin, a member of aspartic proteinases family, is involved in the process of dormancy, viability and germination of seeds (Milisavljevicet al., 2008, Janek et al., 2016, Shen et al., 2018). Seed dormancy, an evolutional strategy, prevents from seeds germination during seed storage, or in stress conditions. The process from dormancy to generation includes three stages: the primary dormancy acquirement with seed maturation, gradual loss of seed dormancy in a subsequent period of seed storage (so-called after-ripening), and finally approach into a nondormant state (Graeber et al., 2012; Ne'e et al., 2017a). Pre-harvest sprouting is cut-short dormancy or dormancy-loss and abnormal generation, which is a severe problem in quinoa production. It is possible the aspartic proteinases, AUR62023656-RA, promotes seed dormancy. Further investigation of the protein could help find the solution to pre-harvest sprouting.

For an early maturation accession, timely harvest seemed to be very crucial to obtain plump grains with nice color, on which the yield depends. Untimely harvest would result in both harms: delayed harvest brings about grains exposing to continuous rainwater and early harvest results in poor grain plumpness. In subtropical areas, timely harvest could get the second benefit as a result that spring rains is the great enemy for quinoa harvest. Spring rain in subtropical areas always goes on for two or three weeks, which almost cover whole harvest season. Pre-harvest sprouting in quinoa causes poor grain quality and results in significant reductions in yield, leading to significant economic losses.

In the past four years, quinoa culture in Xiamen experienced twice three-week spring-rains, respectively in 2016 and 2019 when maturity was closing. Bad grains were collected exposing to continuous spring rains. However, early harvest directly lead to grains with poor plumpness based on morphological index. 


\section{Conclusions}

Seed maturation conversion is an essential stage in plant life, especially for seed economic crops such as quinoa. Proteomics analysis of quinoa assessed proteome changes during seed maturation conversion. Thirteen down-regulated DEPs and four up-regulated DEPs showed dynamic of oleanane-type saponins bio-synthesis, seed generation, seed dormancy, related enzymes such as $\beta$-Amylase, ABA-inducible protein PHV A1, seed storage proteins, LEAs, cyprosin, PAP, and so on. The work enhances our understanding of the biological and physiological characteristics of seed maturation in quinoa, and an important first step towards the genetic improvement of quinoa.

\section{Methods}

\section{Materials}

Experiments were conducted at Fujian Institute of Subtropical Botany's Quinoa Garden, which is located in Xiamen, China ( $118^{\circ} 04^{\prime} 04^{\prime \prime}$, latitude $24^{\circ} 26^{\prime} 46^{\prime \prime}$, annual average temperature $22^{\circ} \mathrm{C}$ ), at an elevation of $63 \mathrm{~m}$ above sea level. The site receives an average rainfall of $1200 \mathrm{~mm} / \mathrm{year}$.

The accession PI596293, was obtained from Plant Germplasm Quarantine Center, USDA. accession PI596293, named COLORADO 407D, is a native ecotype from Colorado., the United states, and is early maturing. COLORADO 407D was characterized with a central axis and secondary and tertiary axes, the large, amaranthiform, compact and glomerous inflorescences, large, yellow, sweet seeds. It was sewed in Oct 26,2017 , eared Dec 10 and harvested on Jan 26, 2018. Inflorescence was collected in both developing stages, respectively. The first stage (Stage I) was 72 days after sewing, and the second stage (Stage II) was 84 days after sewing. Grains of 72 days after sewing is in the eve of seed maturation conversion, and grains 84 days after sewing were mature seeds, edible and dry.

\section{Protein Extraction}

Whole inflorescence was collected, quickly frozen in liquid nitrogen, and then stored at $-80^{\circ} \mathrm{C}$. The sample was grinded by liquid nitrogen into cell powder and then transferred to a 5-mL centrifuge tube. After that, four volumes of lysis buffer (8 M urea, 1\% Triton-100, 10 mM dithiothreitol, and $1 \%$ Protease Inhibitor Cocktail) was added to the cell powder, followed by sonication three times on ice using a high intensity ultrasonic processor (Scientz). The remaining debris was removed by centrifugation at $20,000 \mathrm{~g}$ at $4{ }^{\circ} \mathrm{C}$ for 10 min. Finally, the protein was precipitated with cold $20 \%$ TCA for $2 \mathrm{~h}$ at $-20^{\circ} \mathrm{C}$. After centrifugation at $12,000 \mathrm{~g} 4{ }^{\circ} \mathrm{C}$ for 10 min, the supernatant was discarded. The remaining precipitate was washed with cold acetone for three times. The protein was redissolved in $8 \mathrm{M}$ urea and the protein concentration was determined with BCA kit according to the manufacturer's instructions.

\section{Trypsin Digestion}

For digestion, the protein solution was reduced with $5 \mathrm{mM}$ dithiothreitol for 30 min at $56^{\circ} \mathrm{C}$ and alkylated with 11 mM iodoacetamide for 15 min at room temperature in darkness. The protein sample was then diluted to urea concentration less than $2 \mathrm{M}$. Finally, trypsin was added at 1:50 trypsin-to-protein mass ratio for the first digestion overnight at $37^{\circ} \mathrm{C}$ and $1: 100$ trypsin-to-protein mass ratio for a second 4 h-digestion.

\section{TMT Labeling}

Peptide was desalted using Strata X C18 SPE column (Phenomenex) and vacuum-dried after trypsin digestion. According to the manufacturer's TMT kit protocol, Peptide was reconstituted and processed in 0.5 M TEAB . Briefly, thawed and reconstituted in acetonitrile, then one unit of TMT reagent incubated the peptide mixtures for $2 \mathrm{~h}$ at room temperature and pooled, desalted and dried by vacuum centrifugation.

\section{HPLC Fractionation}

The tryptic peptides were digested into fractions by high pH reverse-phase HPLC using Agilent 300 Extend C18 column (5 $\mu \mathrm{m}$ particles, $4.6 \mathrm{~mm}$ ID, $250 \mathrm{~mm}$ length). Then, peptides were first separated with a gradient of $8 \%$ to $32 \%$ acetonitrile (pH 9.0 ) over 60 min into 60 fractions. Finally, the peptides were fractionated into 18 fractions and dried using vacuum centrifuging. 
Peptides were dissolved in $0.1 \%$ formic acid (solvent $\mathrm{A}$ ) before the tryptic peptides loaded onto a home-made reversed-phase analytical column (15-cm length, $75 \mu \mathrm{m}$ i.d.). The gradient was consisted of an increase from $6 \%$ to $23 \%$ solvent B $(0.1 \%$ formic acid in $90 \%$ acetonitrile) over 38 min, $23 \%$ to $35 \%$ in $14 \mathrm{~min}$ and adding to $80 \%$ in $4 \mathrm{~min}$ then holding at $80 \%$ for the last $4 \mathrm{~min}$, all at a constant flow rate of $400 \mathrm{~nL} / \mathrm{min}$ on an EASY-nLC 1000 UPLC system. The peptides were subjected to NSI source followed by tandem mass spectrometry (MS/MS) in Q ExactiveTM Plus (Thermo) coupled online to the UPLC. The electrospray voltage applied was $2.0 \mathrm{kV}$. The $\mathrm{m} / \mathrm{z}$ scan range was 300 to 1000 for full scan, and intact peptides were detected in the Orbitrap at a resolution of 35,000. Peptides were then selected for MS/MS using NCE setting as 27 and the fragments were detected in the Orbitrap at a resolution of 17,500. A data-independent procedure that alternated between one MS scan followed by $20 \mathrm{MS} / \mathrm{MS}$ scans. Automatic gain control (AGC) was set at $3 \mathrm{E} 6$ for full MS and $1 \mathrm{E} 5$ for MS/MS. The maximum IT was set at 20 ms for full MS and auto for MS/MS. The isolation window for MS/MS was set at $2.0 \mathrm{~m} / \mathrm{z}$.

\section{Database Search}

The obtained MS/MS data were processed using Maxquant search engine (v.1.5.2.8). Tandem mass spectra were searched against quinoa database concatenated with reverse decoy database. The mass tolerance for precursor ions was set as 20 ppm in First search and 5 ppm in Main search,and the mass tolerance for fragment ions was set as $0.02 \mathrm{Da}$. Trypsin/P was specified as cleavage enzyme allowing up to 2 missing cleavages. Carbamidomethyl on Cys was specified as fixed modification and oxidation on Met was specified as variable modifications. FDR was adjusted to $<1 \%$ and minimum score for peptides was set $>40$.

\section{Bioinformatics analysis}

Proteome data was annotated, subcellular Localized and functional enrichment analyzed. Go annotation proteome was derived from the UniProt-GOA database (www. http://www.ebi.ac.uk/GOA/). Then proteins were classified by Gene Ontology annotation based on three categories: biological process, cellular component. Identified proteins domain functional description were annotated by InterProScan (a sequence analysis application) based on protein sequence alignment method, and the InterPro domain database was used. Kyoto Encyclopedia of Genes and Genomes (KEGG) database was used to annotate protein pathway. Also, we used wolfpsort, a subcellular localization predication soft to predict subcellular localization. An updated version of PSORT/PSORT II for the prediction of eukaryotic sequences and molecular function. A corrected p-value $<0.05$ is considered significant.

The resulting MS data were processed using Skyline (v.3.6). Enzyme was set as Trypsin [KR/P], Max missed cleavage set as 0. The peptide length was set as 7-25, Variable modification was set as Carbamidomethyl on Cys and oxidation on Met, and maxvariable modifications was set as 3. Transition settings: precursor charges were set as 2, 3, ion charges were set as 1 , ion types were set as b, y. The productions were set as from ion 3 to last ion, the ion match tolerance was set as $0.02 \mathrm{Da}$.

\section{PRM validation for Targeted MS Analysis}

To determine the reliability sequencing results, original proteins samples were applied to the same LC-MS system used above. According to results from the above assessment, a total of 19 peptides were selected and added to the inclusion list for the PRM assay detection. Full details referenced Hashimoto et al. (2019).

\section{Acknowledgement}

This work was supported by the Xiamen Science \& Techno lodge Project (Grant No. 2016S0974, 2016-2019) and the National Natural Science Foundation of China (Grant No. 31372093$).$

\section{References}


Aloisi, I., Parrotta, L., Ruiz, K.B., Landi, C., Bini, L., Cai, G., Biondi, S., Del Duca, S., 2016. New Insight into Quinoa Seed Quality under Salinity: Changes in Proteomic and Amino Acid Profiles, Phenolic Content, and Antioxidant Activity of Protein Extracts. Front Plant Sci., $18(7)$ :656

Bhargava, A., Schuka, S., Ohri, D., 2006. Chenopodium quinoa - an Indian perspective. Ind. Crops Products, 23(1):73-87.

Burrieza, H.P., Rizzo, A.J., Moura Vale, E., Silveira, V., Maldonado, S., 2019. Shotgun proteomic analysis of quinoa seeds reveals novel lysinerich seed storage globulins. Food Chem., 293:299-306.

Dakhili, S., Abdolalizadeh, L., Hosseini, S.M., Shojaee-Aliabadi, S., Mirmoghtadaie, L.,2019.

Quinoa protein: Composition, structure and functional properties.Theor. Appl. Genet., 112(8):1593-600.

Das, S.S., Gauri, S.S., Misra, B.B., Biswas, M. D.,2013. Purification and characterization of a betanidin glucosyltransferase from Amaranthus tricolor L catalyzing non-specific biotransformation of flavonoids. Plant Sci. 211:61-9.

David, E.J., Yung, S.H., Damien, J. L., Sandra, M. S., Bo, ., Theo, J. A. B., Hajime, O., Katsuhiko, M., Craig, T., Michell, N.S., Najeh, M. K., Ryan, R. R., Aaron, R. S., Nadine, D., Berin, A.B. et al., 2017. Corrigendum: The genome of Chenopodium quinoa. Nature, 542, $307-312$.

Dehaye, L., Duval, M., Viguier, D., Yaxley, J.Job., 1997. Cloning and expression of the pea gene encoding SBP65, a seed-specific biotinylated protein.Plant Mol Biol., 35(5):605-21.

FAO, IFAD, WFP. The state of food security in the world, 2014: strengthening the enabling environment to improve food security and nutrition[EB/OL]. http://www.fao.org/, 2014-12-11.

Fiallos-Jurado, J., Pollier, J., Moses, T., Arendt, P., Barriga-Medina, N., Morillo, E., Arahana, V., de Lourdes Torres, M., Goossens, A.L.,2016. Saponin determination, expression analysis and functional characterization of saponinbiosynthetic genes in Chenopodium quinoa leaves.Plant Sci., 250:188-197.

Fuentes, F.F., Bhargava, A., Martinez, E.A., 2012. Implications of farmers' seed exchanges for on-farm conservation of quinoa, as revealed by its genetic diversity in Chile. J. Agric. Sci., 150:702-716.

Galau, G. A., Hughes, D. W., Dure, L., 1986. Abscisic-acid induction of cloned cotton late embryogenesis-abundant (Lea) Messenger-Rnas. Plant Mol. Biol., 7: 155-170.

Gomez-Caravaca, A. M., lafelice, G., Verardo, V., Marconi, E., Caboni, M. F. Influence of pearling process on phenolic and saponin content in quinoa (Chenopodium quinoa Willd.). Food Chem. 2014, 157, 174-178.

Graeber, K., Nakabayashi, K., Miatton, E., Leubner-Metzger, G., Soppe, W.J., 2012. Molecular mechanisms of seed dormancy. Plant Cell Environ., 35: $1769-1786$

Han, J.Y., Kim, M.J., Ban, Y.W., Hwang, H.S., Choi, Y.E., 2013. The involvement of $\beta$-amyrin 28-oxidase (CYP716A52v2) in oleananetype ginsenoside biosynthesis in Panax ginseng. Plant Cell Physiol., 54(12):2034-46.

Hong, B., Uknes, S.J., Ho, T.H.,1988. Cloning and characterization of a cDNA encoding a mRNA rapidly-induced by ABA in barley aleurone layers.Plant Mol. Biol., 11(4):495-506.

Hu, Y., Zhang, J., Zou, L., Fu, C., Li, P., Zhao, G., 2017. Chemical characterization, antioxidant, immune-regulating and anticancer activities of a novel bioactive polysaccharide from Chenopodium quinoa seeds. Int. J. Biol. Macromol., 99: 622-629.

Isayenkova, J., Wray, V., Nimtz, M., Strack, D., Vogt, T., 2006. Cloning and functional

characterisation of two regioselective flavonoid glucosyltransferases from Beta

vulgaris, Phytochemistry, 67: 1598-1612.

Janek, K., Niewienda, A., Wöstemeyer, J., Voigt, J., 2016.The cleavage specificity of the aspartic protease of cocoa beans involved in the generation of the cocoa-specific aroma precursors.Food Chem., 15, 211:320-8.

Jo, H.J., Han, J.Y., Hwang, H.S., Choi, Y.E., 2017. $\beta$-Amyrin synthase (EsBAS) and $\beta$-amyrin 28-oxidase (CYP716A244) in oleanane-type triterpene saponin biosynthesis in Eleutherococcus senticosus. Phytochemistry, 135:53-63. 
Konishi, Y., Hirano, S., Tsuboi, H. , Wada, M., 2004. Distribution of minerals in quinoa (Chenopodium quinoa Willd.) seeds. Biosci. Biotechnol. Biochem., 68: 231-234.

Kuljanabhagavad, T. , Wink, M., 2009. Biological activities and chemistry of saponins from Chenopodium quinoa Willd. Phytochem. Rev., 8:473-490

Lintschinger, J., Fuchs, N., Moser, H., Jäger, R., Hlebeina, T., Markolin, G., Gössler, W.,1997. Uptake of various trace elements during germination of wheat, buckwheat and quinoa. Plant Foods Hum. Nutr. , 50(3):223-37.

Lopes, C.O., Barcelos, M.F.P., Vieira, C.N.G., de Abreu, W.C., Ferreira, E.B., Pereira, R.C., de Angelis-Pereira, M.C., 2019.. Effects of sprouted and fermented quinoa (Chenopodium quinoa) on glycemic index of diet and biochemical parameters of blood of Wistar rats fed high carbohydrate diet. J. Food Sci. Technol., 56(1):40-48.

Lim, J., Lim, C.W., Lee, S.C., 2018.The Pepper Late Embryogenesis Abundant Protein, CaDIL1, Positively Regulates Drought Tolerance and ABA Signaling. Front Plant Sci., 9:1301.

Mariana, A., Silva, A., Juriaan, R., Timothy, J., Dennis, J.M. F., Wilco, L., Henk, H. , 2019. Structural Plasticity of Intrinsically Disordered LEA Proteins from Xerophyta schlechteri Provides Protection In Vitro and In Vivo.Front Plant Sci., 10: 1272.

Massawe, F., Mayes, S. \& Cheng, A., 2016. Crop diversity: an unexploited treasure trove for food security. Trends Plant Sci., 21:365-368

Medina-Meza, I.G., Aluwi, N.A., Saunders, S.R., Ganjyal, G.M.,2016. GC-MS Profiling of Triterpenoid Saponins from 28 Quinoa Varieties (Chenopodium quinoa Willd.) Grown in Washington State. J. Agric. Food Chem., 64(45):8583-8591.

Mohammad, S.S., Katayoun, Z., Tahmineh, L., Mohammad, A., Malboobi, M.V., 2018. Functional Assessment of an Overexpressed Arabidopsis Purple Acid Phosphatase Gene (AtPAP26) in Tobacco Plants. Iranian J. Biotech. , 16(1):e2024:31-41.

Mundy, J., Rogers, J.C., 1985. Selective expression of a probable amylase/protease inhibitor in barley aleurone cells: comparison to the barley amylase/subtilisin inhibitor. Planta, 169:51-63.

Ne'e, G., Xiang, Y. and Soppe, W.J., 2017a. The release of dormancy, a wake up call for seeds to germinate. Curr. Opin. Plant Biol., 35: 8-14.

Oelke, E.A., Putnam, D.H., Teynor, T.M., Oplinger, E.S., 1992. Quinoa. Alternative Field Crops Manual. University of Wisconsin-Extension. Madison, Wisconsin/center for Alternative Plant and Animal Products, University of MInnesota Extension Service, St Paul, Minnesota

Pertl-Obermeyer, H., Trentmann, O., Duscha, K., Neuhaus, H.E., Schulze, W.X., 2016. Quantitation of Vacuolar Sugar Transporter Abundance Changes Using QconCAT Synthtetic Peptides.Front Plant Sci., 12;7:411.

Rai, A., Suprasanna, P., D'Souza, S.F., Kumar, V., 2012. Membrane topology and predicted RNA-binding function of the 'early responsive to dehydration (ERD4)' plant protein. PLoS One. 7(3).

Rizhsky, L., Liang, H., Shuman, J., Shulaev, V., Davletova, S., Mittler, R., 2004. When defense pathways collide. The response of Arabidopsis to a combination of drought and heat stress. Plant Physiol. 134 1683-1696.

Ruiz, G. A., Xiao, W., van Boekel, M., Minor, M., Stieger, M.『2016. Effffect of extraction pH on heat-induced aggregation, gelation and microstructure of protein isolate from quinoa (Chenopodium quinoa Willd). Food Chem., 209: 203-210.

Saucedo, A.L., Hernández-Domínguez, E.E., de Luna-Valdez, L.A., Guevara-García, A.A., Escobedo-Moratilla, A., Bojorquéz-Velázquez, E., Del RíoPortilla, F., Fernández-Velasco, D.A., Barba de la, R.A.P., 2017. Insights on Structure and Function of

a Late Embryogenesis Abundant Protein from Amaranthus cruentus: An Intrinsically Disordered Protein Involved in Protection against Desiccation, Oxidant Conditions, and Osmotic Stress. Front Plant Sci., 7:8:497.

Schlick, G., Bubenheim, D.L., 1996. Quinoa: candidate crop for NASA's controlled ecological life support systems. In: Janick J, editor. Progress in New Crops. Arlington, VA: ASHS Press. pp.630-640.

Shen, W., Yao, X., Ye, T., Ma, S., Liu, X., Yin, X., Wu, Y., 2018. Arabidopsis Aspartic Protease ASPG1 ffects Seed Dormancy, Seed Longevity and Seed Germination. Plant Cell Physiol., 59(7):1415-1431

Stevens, M.R., Coleman, C.E., Parkinson, S.E., Maughan, P.J., Zhang, H.B., Balzotti, M.R., Kooyman, D.L., Arumuganathan, K., Bonifacio, A., Fairbanks, D.J., Jellen, E.N., Stevens, J.J., 2019. Construction of a quinoa (Chenopodium quinoa Willd.) BAC library and its use in identifying genes encoding seed storage proteins. Food Chem. , 112(8):1593-600

Page $9 / 18$ 
Vega-Galvez, A., Miranda, M., Vergara, J., Uribe, E., Puente, L., Martínez, E. A., 2010. Nutrition facts and functional potential of quinoa (Chenopodium quinoa willd.), an ancient Andean grain: a review. J. Sci. Food Agric., 90:2541-2547.

Wu, G., Morris, C.F., Murphy, K.M., 2014. Evaluation of texture differences among varieties of cooked quinoa. J. Food Sci., 79(11):S2337-45. Vilcacundo, R., Martínez-Villaluenga, C., Hernández-Ledesma, B. , 2017. Release of dipeptidyl peptidase IV. a-amylase and a-glucosidase inhibitory peptides from quinoa (Chenopodium quinoa Willd.) during in vitro simulated gastrointestinal digestion. J. Funct. Foods, 35: 531539.

Vilcacundo, R., Miralles, B., Carrillo, W., 2018. Hernández-Ledesma B in vitro chemopreventive properties of peptides released from quinoa (Chenopodium quinoa Willd) protein under simulated gastrointestinal digestion. Food Res. Int., 105:403-411.

Wang, W.Q., Møller, I.M., Song, S.Q., 2012. Proteomic analysis of embryonic axis of Pisum sativum seeds during germination and identification of proteins associated with loss of desiccation tolerance. J. Proteomics., 21:77:68-86.

Wu, G.Y., 2016. Quinoa Improvement and sustainable production[M]//Kevin Murphy, Janet Matanguiban. (Eds.), Nutritional Properties of Quinoa. Wiley Blackwell, pp.193.

Xu, S.X., Huang, Q.Y., Lin, C.S., Lin, L.X., Zhou, Q., Lin, F.C., He, E.M., 2016.Transcriptome comparison reveals candidate genes responsible for the betalain-/anthocyanidin-production in bougainvilleas. 43(3): 278-286.

Xu, S.X., Huang, Q.Y., Lin, C.S., Lin, F.C., Lin, L.X., Shen, Q.Y., 2015. Rapid generation and analysis of expressed sequence tags to uncovering inflorescence secondary metabolism of Bougainvillea spectabilis 'Splenders' by pyrosequencing. Euphytica 205, 747-759.

Yamada, K., Osakabe, Y., Mizoi, J., Nakashima, K., Fujita, Y., Shinozaki, K., et al., 2010. Functional analysis of an Arabidopsis thaliana abiotic stress-inducible facilitated diffusion transporter for monosaccharides. J. Biol. Chem., 285:1138-1146.

Zevallos, V.F., Herencia, L.I., Chang, F., Donnelly, S., Ellis, H.J., Ciclitira, P.J., 2014. Gastrointestinal effects of eating quinoa (Chenopodium quinoa Willd.) in celiac patients[J]. Americ. J. Gastroenterology, 109(2): 270-278.

Zhou, Y., Jiang, Y., Shi, R., Chen, Z., Li, Z., Wei, Y., Zhou, X., 2019. Structural and antioxidant analysis of Tartary buckwheat (Fagopyrum tartaricum Gaertn.) 13Sglobulin. J. Sci. Food Agric. doi: 10.1002/jsfa.10133.

Zurita-Silva, A., Fuentes, F., Zamora, P., Jacobsen, S.-E. \& Schwember, A. R., 2014. Breeding quinoa (Chenopodium quinoa Willd.): potential and perspectives. Mol. Breed., 34:13-30.

\section{Declarations}

- Ethics approval and consent to participate

The manuscript is based on Ethics approval and consent to participate.

- Consent for publication

The manuscript is based on Consent for publication

- Availability of data and material

The submission includes all data and material, and are available. The supporting data has been uploaded with submission, which can be accessed.

- Competing interests

The manuscript has not any Competing interests.

- Funding

All funding for the studies are listed in the manuscript, together with the names of the principal funding recipients.

- Authors' contributions

Page $10 / 18$ 
SX X: designed the research, preparing manuscript and acquire Funding; QY H: analyze data,materials collecting; ZY L: pictures preparation, manuscript modifying; H YJ: treatment; L CS: data curation; H EM: methodology; L FC : Software.

All authors have read and approved the manuscript.

- Acknowledgement

All funding for the studies in the manuscript, together with the names of people who provided any help for the work, must be listed in the Acknowledgement.

\section{Tables}

Table 1 Morphological characteristics of plant in two developing stages

\begin{tabular}{|c|c|c|c|c|c|c|}
\hline Stage & Mean Plant height $(\mathrm{cm})$ & Mean diameter of inflorescence $(\mathrm{cm})$ & $\begin{array}{l}\text { Mean height of inflorescence } \\
\qquad(\mathrm{cm})\end{array}$ & Leaves color & Leaf axil color & Stem streaks Color \\
\hline Stage $\square$ & 111.2 & 5.4 & 30.5 & green & green & green \\
\hline Stage $\square$ & 107.1 & 5.6 & 32.0 & Green & Green & Green \\
\hline Stage & Mean grain diameter (mm) & Mean grain thickness (mm) & Mean hundred-grain weight (g) & Palea color & Episperm color & Days after sewing \\
\hline Stage $\square$ & 2.2 & 1.1 & 0.22 & green & orange & 72 \\
\hline Stage $\square$ & 2.5 & 1.4 & 0.38 & yellow & orange & 84 \\
\hline
\end{tabular}

Table 2. DEPs summary (Filtered with threshold value of expression fold change and $\mathrm{P}$ value $<0.05$ )

\begin{tabular}{llllll}
\hline Compare group & Regulated type & fold change $>1.2$ & fold change $>1.3$ & fold change $>1.5$ & fold change $>2.0$ \\
\hline Yellow_1/Yellow_2 & up-regulated & 1263 & 1042 & 675 & 287 \\
& down-regulated & 1013 & 824 & 551 & 294 \\
\hline
\end{tabular}

Table 3 Pearson's correlation of quantification

\begin{tabular}{lllllll}
\hline & Yellow_1_1 & Yellow_1_2 & Yellow_1_3 & Yellow_2_1 & Yellow_2_2 & Yellow_2_3 \\
\hline Yellow_1_1 & 1 & 0.78 & 0.9 & -0.73 & -0.74 & -0.79 \\
Yellow_1_2 & 0.78 & 1 & 0.73 & -0.74 & -0.74 & -0.68 \\
Yellow_1_3 & 0.9 & 0.73 & 1 & -0.7 & -0.72 & -0.79 \\
Yellow_2_1 & -0.73 & -0.74 & -0.7 & 1 & 0.89 & 0.84 \\
Yellow_2_2 & -0.74 & -0.74 & -0.72 & 0.89 & 1 & 0.84 \\
Yellow_2_3 & -0.79 & -0.68 & -0.79 & 0.84 & 0.84 & 1 \\
\hline
\end{tabular}

Table 4 GO distribution of up-regulate proteins(Yellow_1-vs-Yellow_2) 


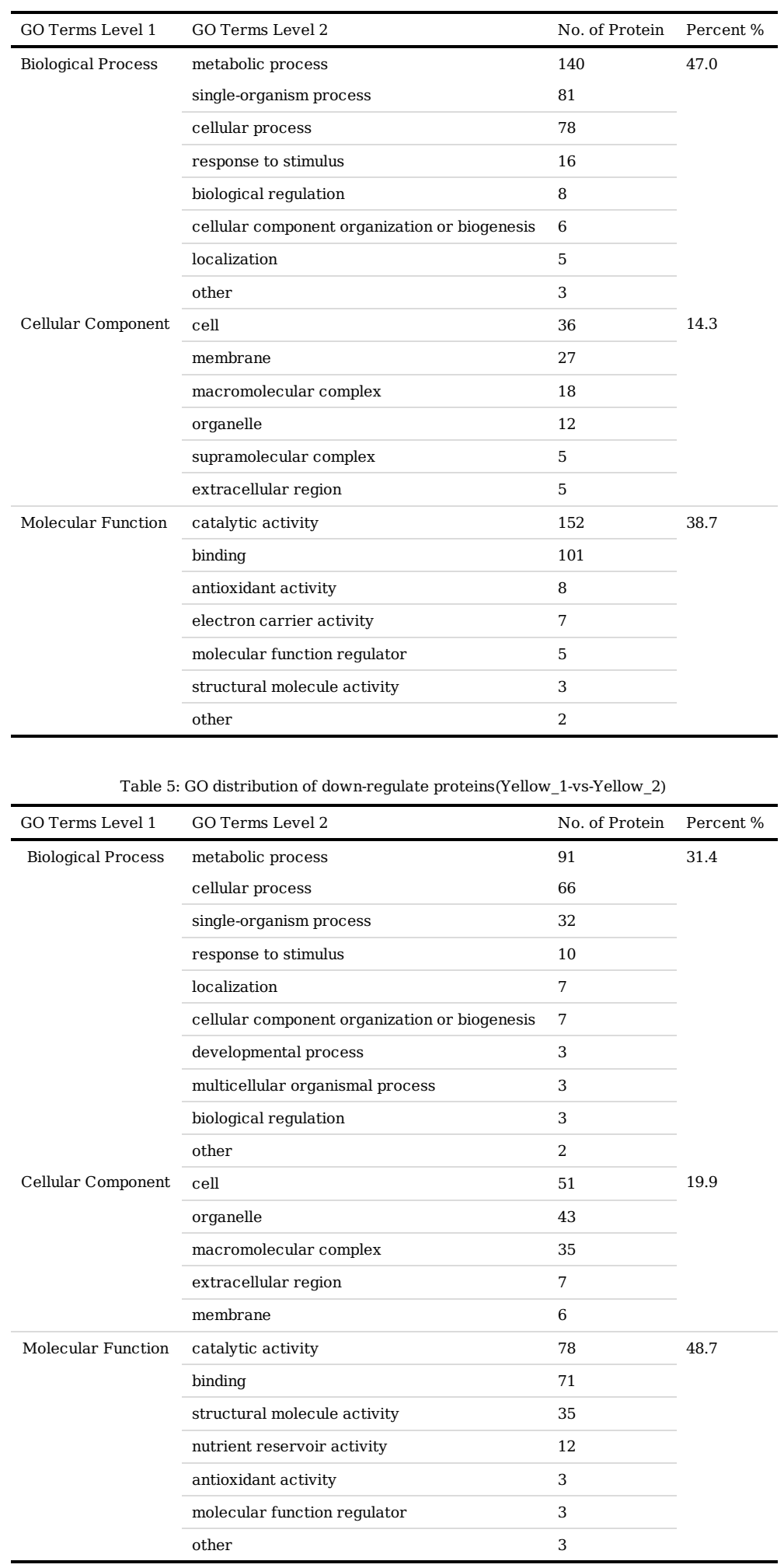

Table 6 Sub-cell location of DEPs (Yellow_1-vs-Yellow_2) 


\begin{tabular}{lll}
\hline Subcellular Location & Number of up-regulate proteins (\% of total) & $\begin{array}{l}\text { Number of down-regulate } \\
\text { proteins (\% of total) }\end{array}$ \\
& & $84(29)$ \\
\hline chloroplast & $111(39)$ & $97(33)$ \\
cytoplasm & $85(29)$ & $56(19)$ \\
nucleus & $36(12)$ & $9(3)$ \\
plasma membrane & $19(7)$ & $17(6)$ \\
extracellular & $15(5)$ & $6(2)$ \\
vacuolar membrane & $8(3)$ & $12(4)$ \\
mitochondria & $6(2)$ & $6(2)$ \\
cytoskeleton & $5(2)$ & $4(2)$ \\
endoplasmic reticulum & $2(1)$ & $1(0)$ \\
Golgi apparatus & 0 & $1(0)$ \\
peroxisome & 0 & $1(0)$ \\
cytoplasm & 0 & 294 \\
Total & 287 & \\
\hline
\end{tabular}

Table 7 Identified DEPs in two developing stages using PRM

\begin{tabular}{|c|c|c|c|c|}
\hline \multirow{3}{*}{$\begin{array}{l}\text { Proteins codes } \\
\text { AUR62017037- } \\
\text { RA }\end{array}$} & \multirow[b]{2}{*}{ Protein description } & \multicolumn{3}{|c|}{ Regulated Type Yellow_1/Yellow_2 Ratio (PRM) ${ }^{a}$ Yellow_1/Yellow_2 Ratio (TMT) ${ }^{\mathrm{a}}$} \\
\hline & & & & \\
\hline & ABA-inducible protein PHV A1 [Vitis vinifera] & Down & 0.09 & 0.134 \\
\hline $\begin{array}{l}\text { AUR62014945- } \\
\text { RA }\end{array}$ & beta-amylase [Beta vulgaris subsp. vulgaris] & down & 0.01 & 0.08 \\
\hline $\begin{array}{l}\text { AUR62002139- } \\
\text { RA }\end{array}$ & 13S globulin seed storage protein 1 [Beta vulgaris subsp. vulgaris] & down & 0.48 & 0.29 \\
\hline $\begin{array}{l}\text { AUR62015569- } \\
\text { RA }\end{array}$ & 13S globulin seed storage protein 1 [Beta vulgaris subsp. vulgaris] & down & 0.34 & 0.30 \\
\hline $\begin{array}{l}\text { AUR62024716- } \\
\text { RA }\end{array}$ & 11S globulin seed storage protein 2 isoform X2 [Beta vulgaris subsp. vulgaris] & down & 0.36 & 0.32 \\
\hline $\begin{array}{l}\text { AUR62003182- } \\
\text { RA }\end{array}$ & vicilin-like seed storage protein At2g18540 [Beta vulgaris subsp. vulgaris] & down & 0.40 & 0.33 \\
\hline $\begin{array}{l}\text { AUR62006523- } \\
\text { RA }\end{array}$ & vicilin-like seed storage protein At2g28490 isoform X2 [Beta vulgaris subsp. vulgaris] & down & 0.37 & 0.28 \\
\hline $\begin{array}{l}\text { AUR62025011- } \\
\text { RA }\end{array}$ & vicilin-like seed storage protein At2g28490 isoform X2 [Beta vulgaris subsp. vulgaris] & down & 0.36 & 0.25 \\
\hline $\begin{array}{l}\text { AUR62042308- } \\
\text { RA }\end{array}$ & seed biotin-containing protein SBP65 [Beta vulgaris subsp. vulgaris] & down & 0.07 & 0.16 \\
\hline $\begin{array}{l}\text { AUR62022650- } \\
\text { RA }\end{array}$ & late embryogenesis abundant protein (LEA) family protein [Medicago truncatula] & down & 0.39 & 0.20 \\
\hline $\begin{array}{l}\text { AUR62004613- } \\
\text { RA }\end{array}$ & late embryogenesis abundant protein (LEA) family protein [Medicago truncatula] & down & 0.18 & 0.15 \\
\hline $\begin{array}{l}\text { AUR62013047- } \\
\text { RA }\end{array}$ & "protein EARLY-RESPONSIVE TO DEHYDRATION 7, chloroplastic [Beta vulgaris subsp. vulgaris]" & down & 0.09 & 0.129 \\
\hline $\begin{array}{l}\text { AUR62025699- } \\
\text { RA }\end{array}$ & $\beta$-amyrin 28-oxidase [Beta vulgaris subsp. vulgaris] & Up & 3.93 & 2.05 \\
\hline $\begin{array}{l}\text { AUR62028163- } \\
\text { RA }\end{array}$ & anthocyanidin 3-O-glucosyltransferase 7 [Beta vulgaris subsp. vulgaris] & Up & 7.46 & 3.188 \\
\hline $\begin{array}{l}\text { AUR62013288- } \\
\text { RA }\end{array}$ & bifunctional purple acid phosphatase 26 [Beta vulgaris subsp. vulgaris] & Up & 5.13 & 2.97 \\
\hline $\begin{array}{l}\text { AUR62023656- } \\
\text { RA }\end{array}$ & cyprosin [Beta vulgaris subsp. vulgaris] & Up & 9.50 & 3.158 \\
\hline
\end{tabular}

a All results were signifificant at $\mathrm{p}<0.05$.

\section{Abbreviations}


ABA, abscisic acid;

AGC, automatic gain control;

BAM, $\beta$-Amylase;

BCA, bicinchoninic acid;

COG/KOG, Clusters of Orthologous Groups/Eukaryotic Orthologous Groups;

DEPs, differential expressed proteins;

ERD, early responsive to dehydration;

GO, Gene Ontology;

KEGG, Kyoto Encyclopedia of Genes and Genomes;

LEA, late embryogenesis abundant proteins;

PRM, parallel reaction monitoring;

TEAB, Triethylamonium bicarbonat;

TMT, Tandem Mass Tag;

UDP, Uridinediphosphate;

UGT, UDP-glycosyltransferase.

Figures 


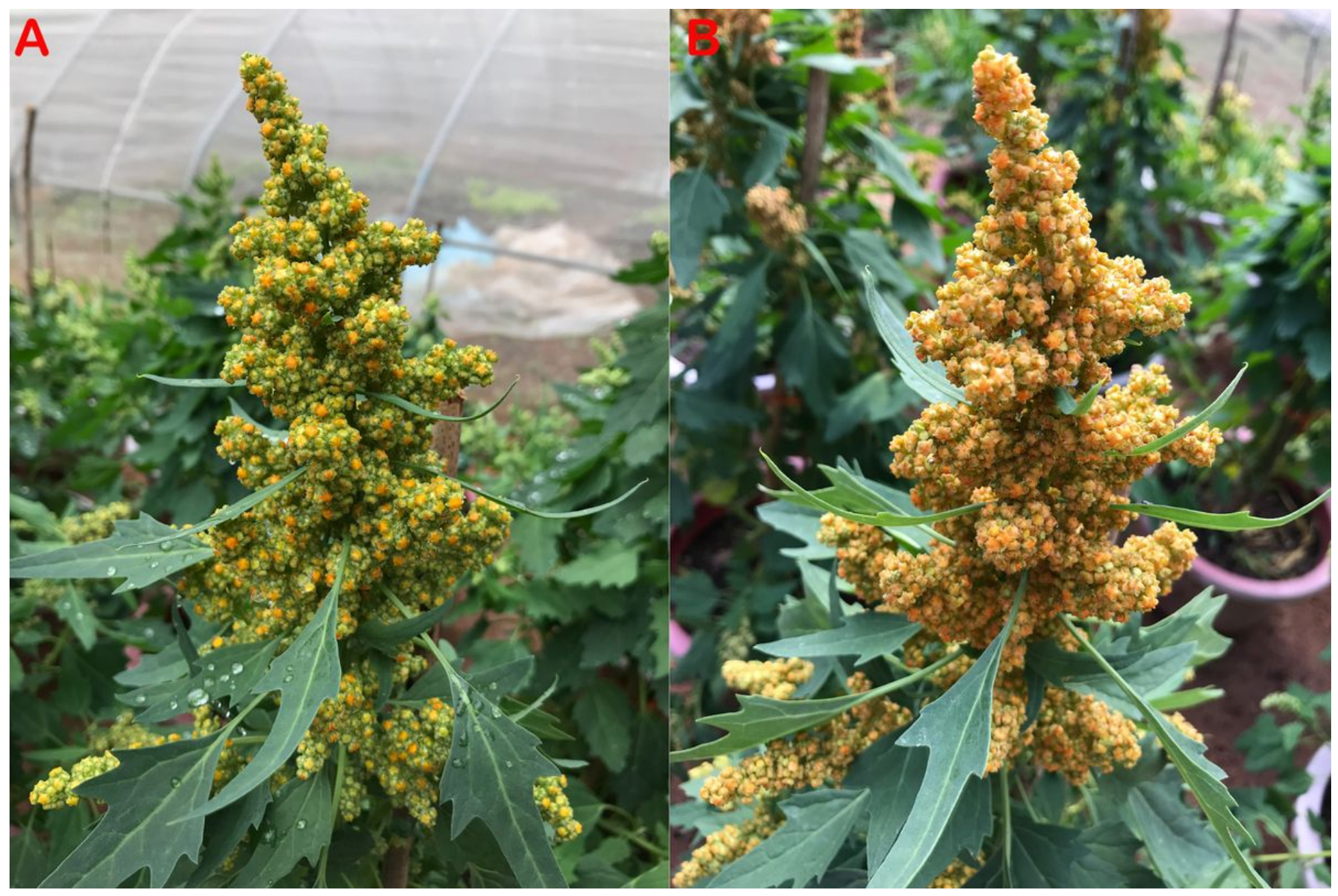

Figure 1

Materials in the study. A is in Stage I and B is in Stage II. 
A

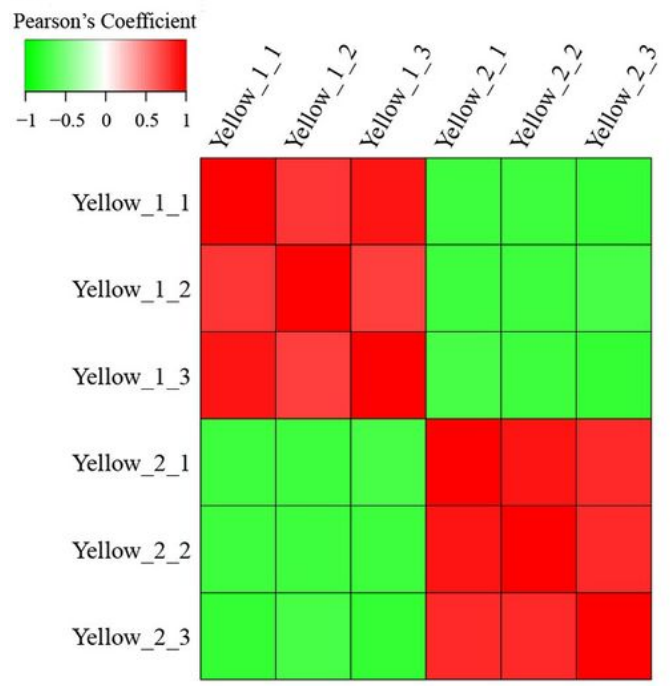

B

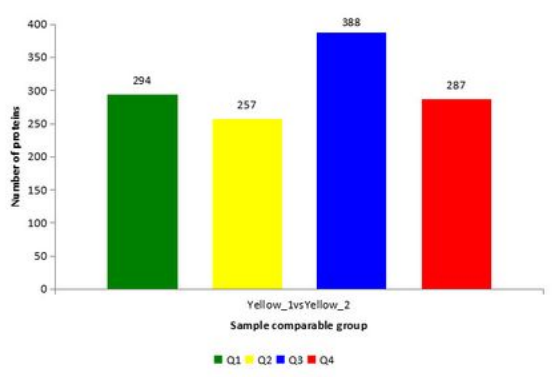

$\mathbf{C}$

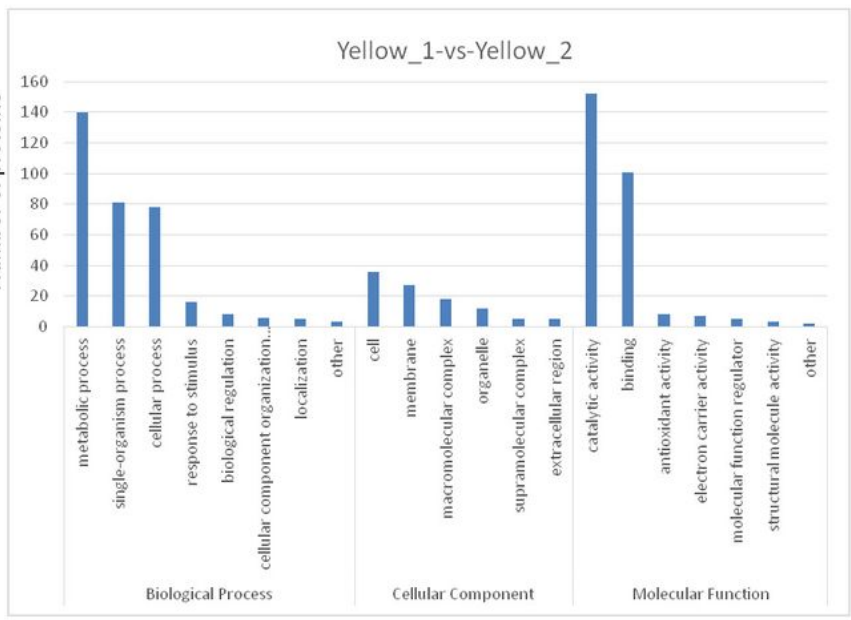

D

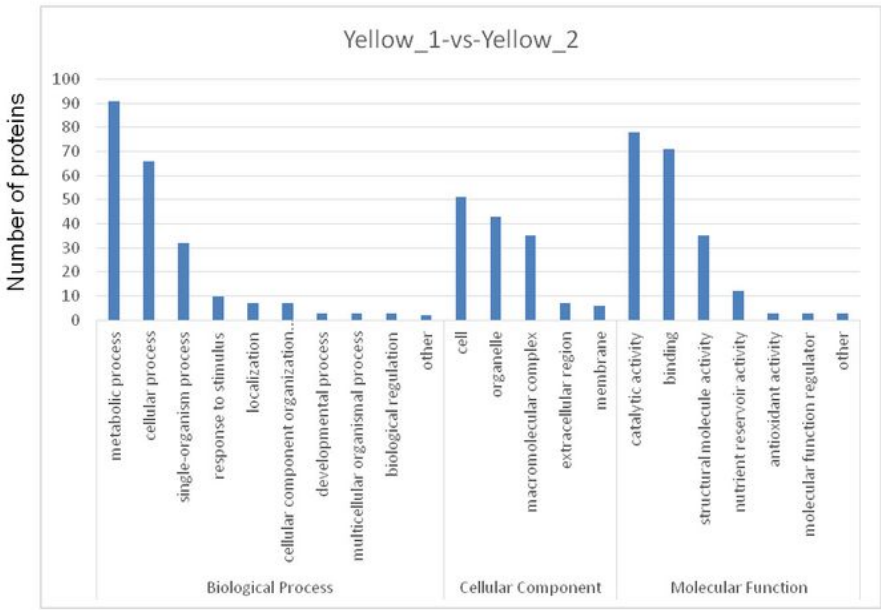

\section{Figure 2}

Quantitative identification and annotation of up- and down-regulated proteins by TMT labeling. (A) Pearson's correlation coeffificients calculated from three biological replicates for each biotype/treatment. (B) Numbers of DEPs based on difference fold in Yellow_1-vs-Yellow_2. (C) GO classification of the up-regulated DEPs in Yellow_1-vs-Yellow_2. (D) GO classification of the down-regulated DEPs in Yellow_1-vsYellow_2. 
A.

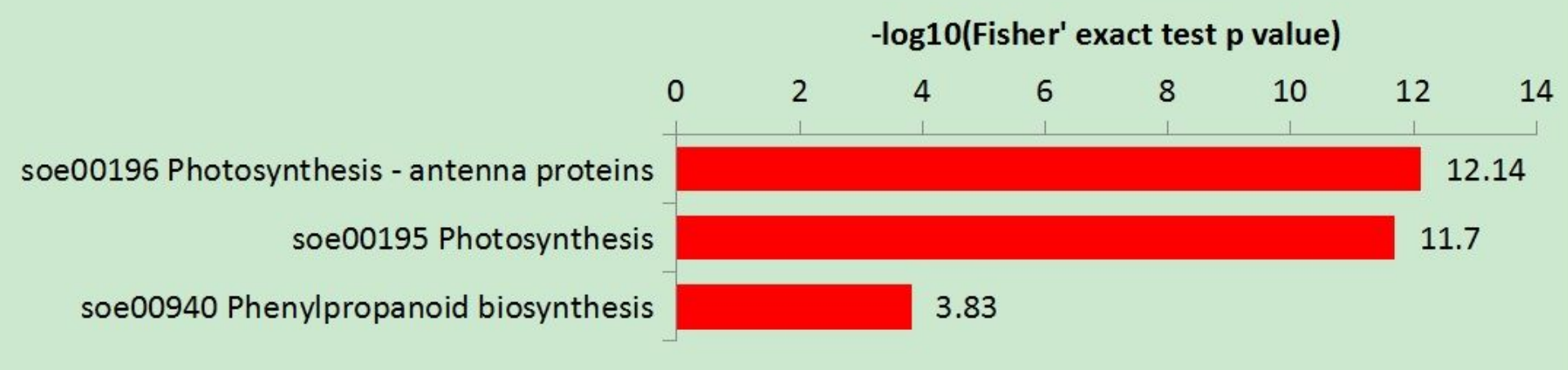

B.

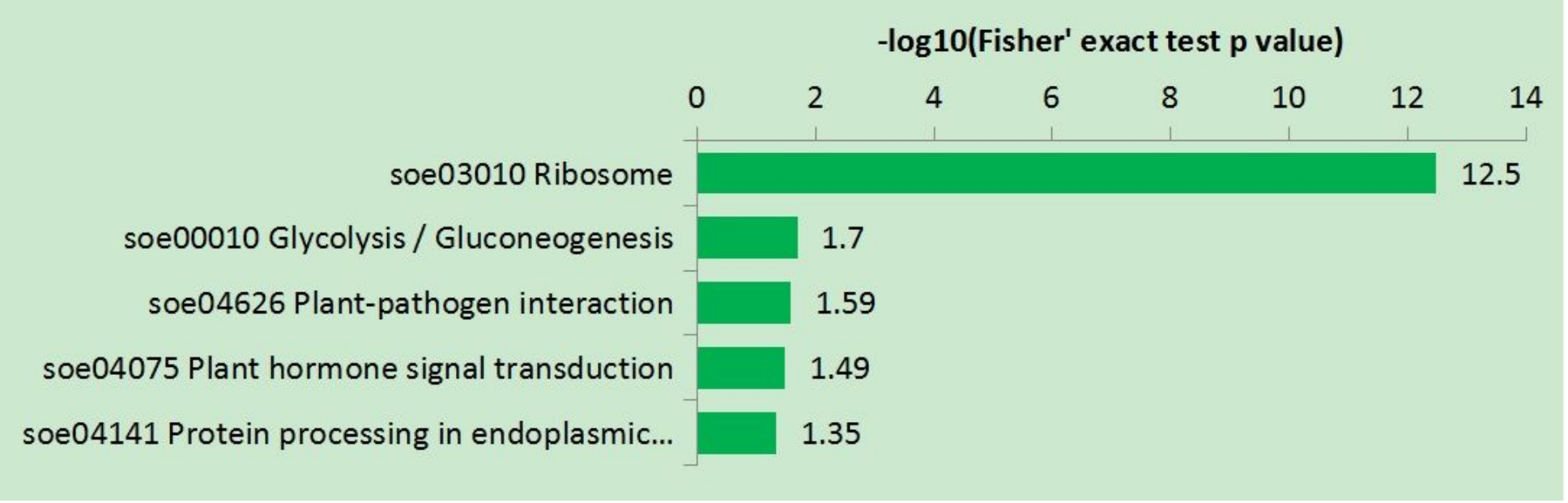

Figure 3

KEGG pathways of up-regulated proteins ( $A$,red) and down-regulated proteins ( $B$, green). 


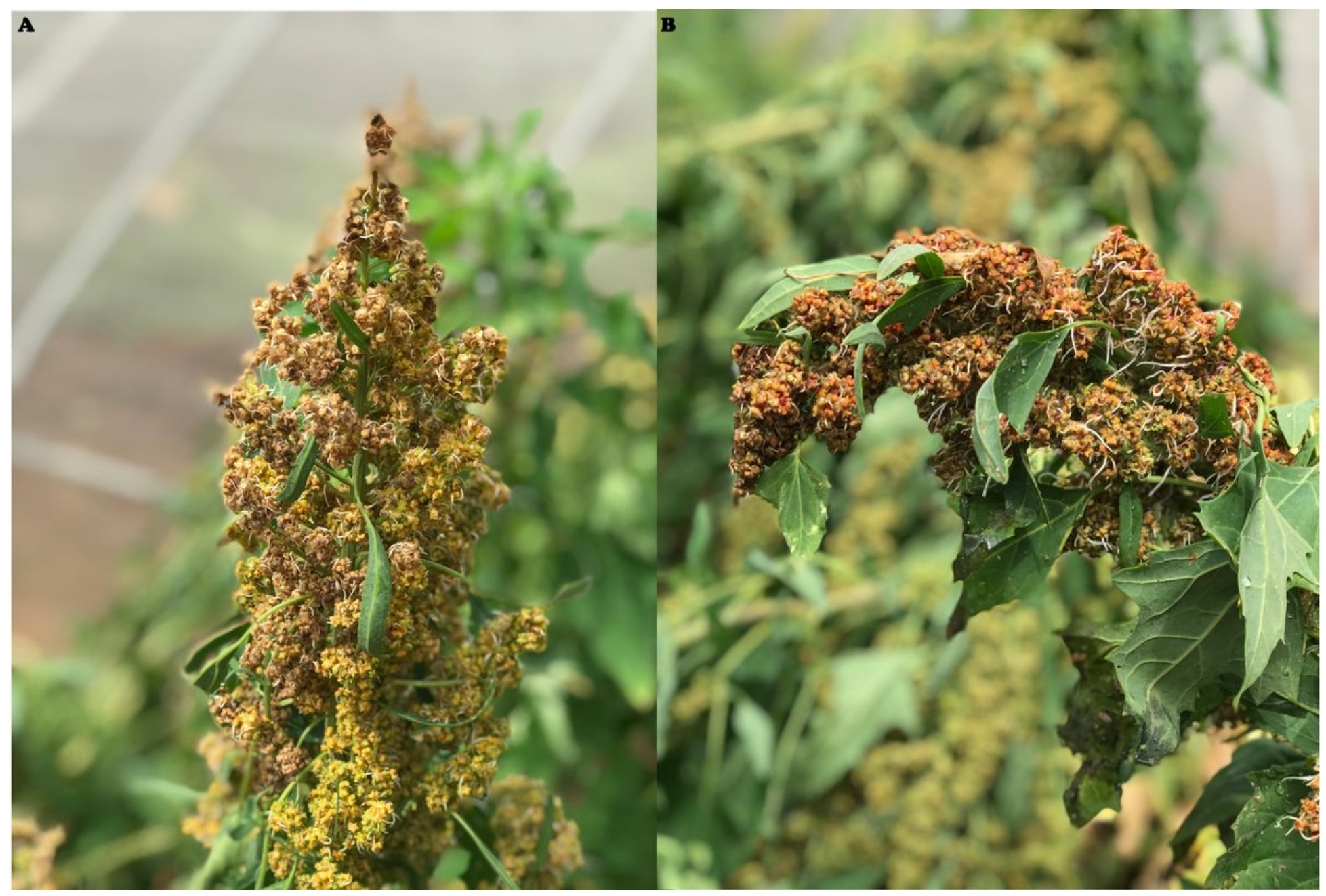

Figure 4

Pre-harvest sprouting in quinoa

\section{Supplementary Files}

This is a list of supplementary files associated with this preprint. Click to download.

- SupplementaryTableS5Yellow1vsYellow2Q4annot.xIsx

- SupplementaryTableS8ProteinGOTermsLevel2Classify.xlsx

- SupplementaryTableS9KEGGpathwayenrichment.xlsx

- SupplementaryTableS2Yellow1vsYellow2Q1annot.xlsx

- SupplementaryTableS10ProteinSubcellularClassify.xIsx

- SupplementaryTableS1Yellow1vsYellow2Qallproteinlist.xIs

- SupplementaryTableS11PRM1Result.xIsx

- SupplementaryTableS7Proteindomainenrichment.xIsx

- SupplementaryTableS3Yellow1vsYellow2Q2annot.XIsX

- SupplementaryTableS4Yellow1vsYellow2Q3annot.xIsx

- SupplementaryTables6allproteinpathwayenrichment.pdf 